\title{
ÁNGEL, ¡QUÉ RARO! \\ PERPLEJIDADES NOMINALES EN \\ LA POESÍA DE ÁNGEL GONZÁLEZ 1
}

Verónica Leuci y Laura Scarano

Universidad Nacional de Mar del Plata / CONICET (Argentina)

Cuando un nombre no nombra, y se vacía, desvanece también, destruye, mata la realidad que intenta su designio. («Palabra muerta, realidad perdida»)

En el presente trabajo nos centraremos en la relevancia del nombre de autor incluido en la obra poética del escritor asturiano, atendiendo a sus efectos y funcionamiento pragmático. En este repliegue discursivo sobre "sí mismo», Ángel González reivindica la posibilidad de plasmar una autorrepresentación, que excede con creces la mera remisión a la persona empírica, pues esta solo se comprende en el cruce de ambas esferas — privada y pública-, entre la proyección autobiográfica y la versión escrituraria. El orden social queda integrado en su autoanálisis, y dentro de él el propio sujeto que nos cuenta su vida, al tiempo de advertirnos sobre los límites de tal gesto, por su estatuto verbal e imaginario (Scarano, 2011a). La pulsión figurativa de esta escritura dotada de nombre autoral revierte sobre el lector, que no puede sustraerse a la seducción que ejerce sobre él la función denotativa del antropónimo, de efecto «encantatorio» (al decir de Philippe Lejeune), proyectando un «aura de verdad» sobre el poema, pero preservando un incesante «movimiento de vaivén» (Combe, 1999: 145), del autor empírico al ser de papel. FFI2011-26412, financiado por el Ministerio de Economía y Competitividad. 
Sabemos que el sujeto lírico se construye como «imaginario» o «ficcional»y nos propone un «relato de identidad», una versión filtrada por una subjetividad en proceso, imposible de sujetar de manera unívoca a los avatares extratextuales. Pero en esta operatoria, los datos de la biografia del autor incorporados al texto colaboran con el efecto de realidad que propicia el antropónimo. La expresión «ficción-autor» (Scarano, 2013 y 2014), para aludir a la construcción mediatizada de un personaje "nombrado" $\mathrm{y}$ «fechado», junto con sus desdoblamientos, máscaras y demás figuraciones, nos permitirá discutir los juegos y alianzas establecidas entre yo lírico y autor.

\section{LOS ESPEJOS DE LA IRONÍA}

Una de las cuestiones principales en la constitución de la «autopoética» de Ángel González es el buceo en la identidad del yo y, en ese movimiento, es manifiesta su preocupación por la construcción explícita de un "personaje poético» al que le cede su propio nombre. Tras el modelo de Antonio Machado y sus apócrifos, enfatiza en su trabajo ensayístico la inventio creadora, la conciencia del artificio que lleva a objetivar su voz en una identidad otra. Esta apuesta, como ha señalado el autor, responde especialmente a lo que puede denominarse una "estética del pudor», o una retórica, un «tono» singular, asociados al recato; se edifica una voz que rehúye la grandilocuencia y la altisonancia tanto como el patetismo, la confesionalidad y la expresividad directa. Por tanto, la distancia que ofrece el personaje poético será la matriz que acompañe otras tantas estrategias de su poesía - correlato objetivo, parodia, sátira o, muy especialmente, la ironía-, para obtener «un tono de distanciamiento que aligera la peligrosa carga sentimental de ciertas actitudes, algo importante para una persona que, como yo, intenta escribir poesía desde sus experiencias conservando un mínimo de pudor» (González, 1980: 19).

La «gran dosis de ironía» (Benson, 1981:570) presente en su poesía ha sido destacada no solo por el propio poeta sino, de manera prácticamente unánime, por todos sus críticos, ya desde los tempranos y clásicos trabajos de Emilio Alarcos, José Olivio Jiménez, Dionisio Cañas o Douglas K. Benson, hasta las lecturas más actuales. Este elemento constituye uno de los motores principales de su escritura: no es solo un procedimiento o una figura retórica, sino más bien una visión particular del mundo y de la escritura. Esta se observa especialmente 
a partir de su libro de 1962, Grado elemental, pero recorre como una constante toda su trayectoria lírica.

Este dispositivo - que comparte con otros coetáneos, como rasgo generacional - se destaca en primer término como una de las tantas técnicas o procedimientos (al igual que la alegoría, el símbolo, etc.) para burlar o eludir la mirada vigilante del censor (como el propio González ironiza, la inversión del significado que exige la operación irónica muchas veces excedía las limitadas capacidades mentales de dichos sujetos [1980:18-19]). En segundo lugar, la ironía como principio constructivo supone la multiplicidad, la relatividad, la convivencia de puntos de vista disímiles; habilita así una innegable cuota de escepticismo porque permite la eficacia crítica — renovando los trazos gruesos y altisonantes de los sociales más ortodoxos o panfletarios - y, a la vez, impide «la pretenciosa formulación de las pretendidas verdades absolutas», al introducir «en la afirmación el principio de la negación» ${ }^{2}$.

Como hemos dicho, la ironía le permite distanciarse de la carga sentimental, del confesionalismo o una expresividad lírica cuasi-directa $^{3}$. En palabras de Gil de Biedma, la ironía opera como una «sordina» frente a los excesos expresivos o cualquier "exaltada tesitura lírica» (1980: 67).Y en esta búsqueda, en pos del recato y como respuesta al pudor, la creación de un personaje poético es una de las técnicas centrales en la obra gonzaliana para lograr objetividad y distancia de sí mismo. En relación con la temática identitaria, la ironía adquiere en su obra una importancia fundamental, pues no solo habilita ese «tono de distanciamiento» por la creación de un personaje otro, sino que permite los vínculos más complejos con la idea de «autocrítica» y «autoparodia» (Ballart: 1994). Y de paso sirve de basamento para los giros desacralizadores con que será leído ese mismo personaje en poemarios más tardíos, a través de una renovada cosmovisión que pone el acento en la fragmentariedad, el relativismo, la pluralidad o la ambigüedad.

2 Como la crítica en general ha observado, la ironía permite el ingreso de poemas testimoniales, pero priorizando el multiperspectivismo, que «crea una rica visión de la vida y una rica experiencia que incluye, pero que también supera, a lo político social» (Benson, 1981: 571). Dionisio Cañas aludirá en este sentido a la "polifonía poética» de González, que supone esa necesidad «de contemplar una y otra vez el objeto a que se enfrenta, pero desde variados puntos de vista, y de dar expresión a esas múltiples perspectivas desde una correspondiente pluralidad de tonos» (1980: 5).

3 Cfr. los trabajos sobre la ironía de Kirkpatrick, Aguiar e Silva, Abuín González y Ballart — citados en la bibliografia — así como la minuciosa lectura sobre esta temática que realiza Marcela Romano (2003). 


\title{
2. LA CONSTRUCCIÓN DE «ÁNGEL GONZÁLEZ»
}

El nombre propio del autor inaugura su obra poética en el texto inicial de la sección "Áspero mundo», de su primer poemario homónimo. El texto titulado «Para que yo me llame Ángel González» —uno de sus poemas más citados y recordados- permite condensar y traducir la preocupación social, el anclaje en un tiempo que es tanto metafísico como marcadamente histórico en sus primeros libros, a través de un sujeto que se manifiesta con su rostro y su nombre civil, con una identidad tanto individual como genealógica; el yo es parte de la atávica especie y de la historia de la humanidad:

\author{
Para que yo me llame Ángel González, \\ para que mi ser pese sobre el suelo, \\ fue necesario un ancho espacio \\ y un largo tiempo: \\ hombres de todo mar y toda tierra, \\ fértiles vientres de mujer, y cuerpos \\ y más cuerpos, fundiéndose incesantes \\ en otro cuerpo nuevo. \\ Solsticios y equinoccios alumbraron \\ con su cambiante luz, su vario cielo, \\ el viaje milenario de mi carne, \\ trepando por los siglos y los huesos (2004: 15).
}

En este texto inaugural, que permite ser leído como un «prólogo» a su obra, la mención inicial del nombre construye en este caso un «sujeto-consecuencia», resultado del despliegue diacrónico de una temporalidad en la que se conjuga lo cronológico y lo cosmológico. La historia de la humanidad aparece fundida en la carne, en el ser de este sujeto autoral. Se condensa en la utilización onomástica la apuesta realista de González, de re-humanización y desacralización subjetiva, que replica cualquier cariz «torremarfilista» o de exaltación egocéntrica del yo, concebido como demiurgo, vate o genio creador. El personaje que levanta el telón se reafirma pues en su singularidad, pero como parte del colectivo histórico que le sobreimprime su nombre civil, en la senda teorizada por Pierre Bourdieu: el acto nominal de bautismo supone un estado de "unificación del yo» en distintos estados del campo, otorgándole un estatuto puntual como parte de la vida social (1997: 77). Tiende así al autorreconocimiento en la creación de un personaje que, en un doble juego, tanto objetiva al yo en otro como, 
al otorgarle su nombre a este, le sobreimprime los rasgos históricos de la figura autoral.

En este sentido, en la tensión dialéctica entre intimidad/sociedad, entre historias/Historia, entre singularidad y proyección social, es significativo el valor simbólico que adquiere el antropónimo como compendio de dichas conjunciones y pares complementarios. «Ángel» y «González» anudan también estas tensiones, en la yuxtaposición del nombre de pila que reenvía a un individuo puntual, junto al patronímico que, en cambio, remite a estos «hombres de todo mar y toda tierra» en relación con las raíces genealógicas desconocidas de dicho apellido en la onomástica peninsular, cuestión sobre la que ha reflexionado el propio escritor en una entrevista con Campbell: «El poema es una especie de recorrido por mi árbol genealógico, por otra parte anónimo: a los González no hay quien los rastree por la genealogía hispánica. Es el árbol genealógico del sufrimiento, a lo largo de generaciones enteras, de la plebe o de la gleba» (en Campbell, 1970:373).

Este «nombre familiar» (patronímico) representa y contiene desde el espacio nominal el transcurso cronológico que plantea el texto en diversos niveles, para dar cuenta de una identidad que se afirma no por su aislamiento y singularidad sino, en contraste, por los lazos que la anudan intrínsecamente con la historia, «a través de los siglos y los huesos». Esta imagen de poeta que se presenta en esta página inaugural conjuga, a partir del nombre propio, una postura que concierne tanto al Ángel González «de papel» como al ser humano biográfico. En esta incorporación subyacen pues la visión pesimista, el «árbol genealógico de sufrimientos", como decía el poeta, por un lado; junto con el énfasis muy notorio que, en la línea machadiana, presenta al sujeto como un hijo de vecino, revalidando el perfil humano, de «hombre bueno» y sencillo, parte de una «familia [que], en cuanto te remontas un par de generaciones, está integrada por campesinos muy pobres» (ibíd.: 373).

Si el apellido «González» cobija bajo sus letras lo anónimo, lo plural y corriente en referencia a la historia (española, principalmente), el nombre de pila «Ángel», amén de su valor designativo, le permite establecer filiaciones de índole literaria. Como ha advertido Antonio Armisén en su minucioso estudio del poema, este nombre permite vincularlo con otros poetas, algunos de ellos coetáneos, que acuden también a esta imagen en sus poéticas ${ }^{4}$. La temática en torno de las

4 Decíamos antes que este poema ha sido uno de los más conocidos y estudiados de la obra de González, ya desde sus primeros estudiosos, como Alarcos, en su trabajo de 1969 (luego recogido en 1995), Benson (1981), Sobejano (1987), entre otros. Amén de ellos, queremos destacar trabajos más recientes que se han 
relaciones angélicas y teologales y la tradición poética atraviesa la historia literaria, en muchos casos, en cercanía con la obra gonzaliana (Rafael Alberti con Sobre los ángeles, Vicente Aleixandre con Sombra del paraíso, etc.); entre los más próximos, por su parte, tal vez el más evidente y conocido sea Blas de Otero, con su afamado Ángel fieramente humano de 1950, y José Ángel Valente incluye un poema titulado «El ángel» en $A$ modo de esperanza de $1955^{5}$.

Es interesante advertir asimismo el guiño lúdico entre su nombre y el significado a que este significante alude, en una práctica anfibológica que recorrerá la poética de González. Los alcances connotativos del nombre en el segundo verso destacado, que remiten en la tradición cristiana "al espíritu celeste criado por Dios para su ministerio» (DRAE), contrasta luego con la clara postura de anti-trascendentalismo que otorga el mismo valor semántico a «carne» $\mathrm{y}$ «ser».Así, la dilogía en la convivencia entre nombre propio y nombre común habilitada por la coincidencia entre referencia nominal y sustantivo es insinuada ya en esta operatoria inicial, al contrastar la dimensión humana e histórica, «que pesa sobre el suelo», con la alusión metafórica al carácter etéreo de sus acepciones religiosas.

La enunciación entonces está a cargo, como hemos dicho, de un «sujeto-consecuencia», que no es más que «resultado», "fruto», caracterizado negativamente: «lo que queda, podrido, entre los restos». Esta postura adversa y negativa remite a ese marcado cariz antiheroico que delinea una visión de la subjetividad definida por la derrota y el fracaso. No obstante, se matiza al final al otorgarle al sujeto un carácter noble, destacando su perseverancia en la lucha:

\author{
Esto que veis aquí, \\ $\tan$ solo esto: \\ un escombro tenaz, que se resiste \\ a su ruina, que lucha contra el viento, \\ que avanza por caminos que no llevan \\ a ningún sitio. El éxito \\ de todos los fracasos. La enloquecida \\ fuerza del desaliento... (2004: 15)
}

ocupado de este poema: el del ya citado Armisén, de 1998, y también el de Mauro Caffarato, titulado «La importancia de llamarse Ángel González» (2008).

5 Señala Armisén que el tema teológico y poético de las pretensiones angélicas y su tradición literaria es muy extenso y cita estudios relevantes, como el libro de J. Jiménez, El ángel caído. La imagen del ángel en el mundo contemporáneo (1982), el de H. Bloom, Presagios del milenio. La gnosis de los ángeles, el milenio y la resurrección (1996), etc. (1998: 137). 
En este retrato se pone de relieve la tenacidad idealista, que permite ser leída en analogía con un renovado Quijote contemporáneo, que no se da por vencido y lucha con afán por causas perdidas. De este modo, este primer rostro de la identidad autoficcional resume y está en consonancia con aquellos «dobles» o alter egos posibles y fluctuantes (de textos como «El mendigo», «Historia apenas entrevista», «Yo mismo» o "El derrotado», todos de Sin esperanza, con convencimiento), que salpican las páginas de sus primeros libros, como aristas diversificadas de una subjetividad polifacética congregada en torno a la idea de derrota, fracaso, imposibilidad, del lado de los vencidos, pero sin claudicar nunca.

En el poema «Me basta así», de Palabra sobre palabra (1965), el hablante se presenta, ya en el nivel paratextual, a través de la primera persona del singular, para exhibir una conjetura sobre su ser:

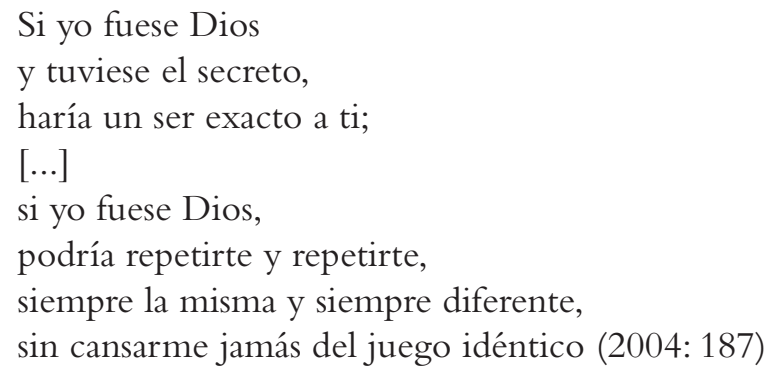

Se trata de un sujeto que se goza en el simulacro demiúrgico, que fabula con repetir — crear- una y otra vez su objeto amoroso (temática que se condice con el tenor amatorio de los cinco poemas restantes del volumen). Sin embargo, la presencia también aquí del nombre propio, sobre el final, permite reflexionar sobre nuevas cuestiones:

$$
\begin{aligned}
& \text { Si yo fuese } \\
& \text { Dios, haría } \\
& \text { lo posible por ser Ángel González } \\
& \text { para quererte tal como te quiero. }
\end{aligned}
$$

Otra vez aparece el antropónimo, que diseña una segunda faceta del sujeto autoficcional, continuando la estela de «Para que yo me llame...». El nombre propio es el nombre que hace plena la palabra poética, es el que reafirma la voz y la identidad del sujeto. A la vez, la elección onomástica revalida la composición «en su humana contingencia: desde la dimensión temporal, desde la limitación humana, desde la negación de la trascendencia, existe una felicidad por horas 
y a ella se aferra González» (Payeras, 2009: 155). No puede ser otro diferente, solo «Ángel González». Un ser sujetado a un nombre que lo nombra en plenitud, como sujeto amoroso. La explícita configuración de este personaje nominado en sus primeros libros, que acude al nombre de autor para afirmar la estatura humana del sujeto, permite dar cuenta de la veta más realista de su rostro poético, en afinidad no solo con su discurrir crítico o ensayístico sino también, especialmente, con la matriz autopoética —o metapoética— que despliega en esta primera sección de su obra y que dialoga, espejo y complemento, con los cauces autoficcionales.

\section{UN «ÁNGEL»RARO: EL DESCONCIERTO NOMINAL}

En 1967, Tratado de urbanismo representa una quiebra respecto de estos planteos iniciales a partir de un texto "bisagra», que retoma y revierte las formulaciones anteriores, titulado "Preámbulo a un silencio». Aquí se exhibe un cuestionamiento nítido (al tiempo que provisional) respecto de muchas convicciones de sus primeros poemarios, más afines a la palabra "esperanzada» del realismo socialista de los $40^{6}$. Y emerge una visión escéptica respecto del acto poético y los alcances de la poesía, enunciada bajo la desconsoladora admisión de «la inutilidad de todas las palabras». A partir de aquí, es posible advertir una segunda fase en su obra, más próxima a la «antipoesía», con un tratamiento irreverente, paródico y desmitificador. En este sentido, los títulos de los siguientes poemarios son sugerentes, desacralizando la poesía a través de una pretendida objetividad: Procedimientos narrativos, Breves acotaciones para una biografía, o Muestra, corregida y aumentada, de algunos procedimientos narrativos y de las actitudes sentimentales que habitualmente comportan.

«Preámbulo a un silencio», incluido en la sección "Ciudad uno", presenta una nueva autonominación que, empero, se distancia de sus

6 González se ha referido en varios lugares a la presencia del compromiso en su poesía y en la de sus compañeros; a la utopía engagée que alienta la escritura de los sociales que, empero, no es una búsqueda ingenua en la que se equipara «decir» $\mathrm{y}$ «hacer». Así, por ejemplo, se refiere a estas cuestiones al hablar del poema que nos atañe, «Preámbulo a un silencio», en entrevista con Laura Scarano: «Nosotros nunca creímos - ni lo creyó Gabriel Celaya - que la poesía es una herramienta para transformar al mundo; eso es un "dictum", un aforismo que como tal aforismo poético hay que entenderlo; sin embargo, creíamos que algo se podía y se debía hacer, y que eso servía para algo. Yo creo que sirvió para algo» (2003: 164). 
apariciones iniciales, en primer término, porque se abandona el uso del patronímico. Solo «Ángel», aquí, representa la versión autoficcional del trazado identitario. El sujeto se repliega; abandona su labor de «vocero» o testigo (anclada la mirada sobre la situación históricopolítica), y deviene un yo desengañado y escéptico, cuestionando las propias posibilidades de representar lo real y a sí mismo. Y en la máscara autoficcional esta actitud alcanza su grado máximo:

Eso es cierto, tan cierto

como que tengo un nombre con alas celestiales

arcangélico nombre que a nada corresponde:

Ángel,

me dicen,

y yo me levanto

disciplinado y recto

con las alas mordidas

- quiero decir: las uñas-

y sonrío y me callo porque, en último extremo,

uno tiene conciencia de la inutilidad de todas las palabras

(2004: 229-230).

Es el nombre de pila el medio por el cual se simboliza el extrañamiento frente a la posibilidad de la representación, y es este mismo elemento el que le permite reflexionar — paradójicamente, desde la poesía— sobre la inutilidad del lenguaje. El «Ángel González» que era resultado, fruto, un "escombro tenaz», el que luego conjuraba a Dios para perseverar en su estatura humana dotado de nombre civil («si fuese Dios»), es ahora un sujeto vacío, sin apellido, ajeno: «Ángel, me dicen». Un nombre que no nombra («que a nada corresponde»). La dilogía aquí explícita -insinuada más sutilmente en el primer texto que hemos visto- abre una brecha entre sustantivo propio y común. El espesor semántico es explotado en una apropiación que parece tender más hacia la connotación que hacia la designación, como símbolo de ese vaciamiento nominativo, postulado en torno de la problematización del vínculo palabra/cosa.

De este modo, comienza a delinearse una nueva figuración del personaje poético, que irá diferenciándose de manera cada vez más nítida de sus irrupciones primeras. El propio González señala que, en este segundo momento de su obra, toda esa apropiación de usos formularios y convencionales — "procedimientos», «tratado», «muestra», «acotaciones»— responde a un interés por «salir del personaje poético que mis libros anteriores habían configurado» (1980: 22). En un camino cercano al explorado por Gil de Biedma, su afán era crear un 
"autor apócrifo", "pero estando tan próximo el ejemplo de Machado me pareció una solución arriesgada» (ibíd.). Por eso la manera de distanciarse será, por un lado, centrarse en los esquemas (calambur, glosas, apotegmas e, incluso, formas musicales, como tango, canción y moldes tradicionales: soneto, elegía, oda, égloga); por el otro, presentar una versión más difuminada del yo en sus vínculos autobiográficos. Ensayará una renovación «formal» de la utilización nominal - prescindiendo del apellido- y explorará los seductores juegos con la autoficción y la metapoesía, que ahondarán sus cuestionamientos en torno de la estabilidad y consistencia del yo.

En primer término, el antropónimo asomará nuevamente en el poema «Siempre lo que quieras», incluido en Breves acotaciones para una biografía (1971). El nombre revela una nueva cara subjetiva que pone de relieve ostensiblemente la ambigüedad en su trazado. La identificación con el autor empírico surge obviamente de la coincidencia nominal; no obstante, no es empleado estrictamente con función designativa, sino como objetivación, que cosifica al sujeto, convertido en umbral («puerta») hacia lo incierto. Dicen los últimos versos: «Pero ya te lo dije: / cuando quieras marcharte esta es la puerta: / se llama Ángel y conduce al llanto» (2004: 261). La voz en primera persona no coincide con el «Ángel» objetivado, que se presenta bifronte y nos impele a dudar sobre sus contornos extratextuales, en su carácter metafórico de «nombre-salida».

Es un espacio donde el nombre connota la extrañeza del ser; no inmoviliza al yo sino que lo disemina. Y esto supone un giro en la trayectoria nominal gonzaliana, apuntando más hacia la distorsión y la disociación que al reconocimiento de esa huella. Porque sabemos que no siempre el nombre propio del autor emergente en el texto es factor unívoco de cohesión; por el contrario en la obra gonzaliana será cada vez más punto de fuga, índice de una deixis fantasmal que no deja de disolverlo, como su emblemático poema «De otro modo», del libro Deixis en fantasma (1992), lo muestra:

Cuando escribo mi nombre, lo siento cada día más extraño.

¿Quién será ese? -me pregunto.

Y no sé qué pensar.

Ángel.

Qué raro (2004: 445). 
Resuena aquí de manera indudable el poema homónimo de Federico García Lorca («De otro modo») del libro Canciones (1927), que concluye con un fatal extrañamiento del hablante auto-nominado: «Entre los juncos y la baja tarde, / iqué raro que me llame Federico!» ${ }^{7}$. Aquellas voces en diáspora, que las sucesivas modulaciones vanguardistas de Lorca explotarían, construirán progresivamente una subjetividad en proceso, en transformación, en búsqueda dialéctica del otro. La voz de Canciones es una voz sintética, que apresa las impresiones de un sujeto oculto, casi secreto e impersonal. Desde una visión estetizante de la naturaleza que lo rodea, «campo», «vientecillo», «aire», «ramas», «río» funcionarán como emblemas metafóricos de un paisaje simbólico, en donde el sujeto es evocado, no en su individualidad humana, sino como «estribillo de estribillos», eco de ecos, traspasado por un velo mítico que lo desdibuja en sombras, resonancias, fusiones. Lorca modula aquí un sujeto extrañado de su propio nombre, de una identidad unívoca y uniforme que lo separa del cosmos y del ritmo natural de las cosas que viven y mueren. «Federico» es el nombre legal que inmoviliza al ser y lo detiene en una identidad pautada, que lo encarcela en un vocablo radicalmente definidor y violentamente referencial, que el hablante rechaza. La experiencia de la poesía lo despoja paradójicamente del nombre propio, lo disuelve entre los otros, lo hace «otro». «Federico» nombraría el límite cerrado, clausurando una experiencia, como la artística, que se define por la integración en el Todo panteísta y la comunión con lo universal.

«Federico» es revivido en su "otro modo» de autonominarse, aboliendo la clausura del nombre civil impuesto desde fuera por la norma. Tras su estela dice González: «Cuando escribo mi nombre, / lo siento cada día más extraño».Y en el final de su texto ahonda aquella disyunción intuida por Lorca (aunque pertenezca a otro imaginario): «¿Quién será ese? — me pregunto. /Y no sé qué pensar. // Ángel. // Qué raro». Deixis ( $y$ o) y nombre propio conviven, alternando la pulsión fantasmática de la primera con el simulacro referencial del segundo. El nombre que los enlaza sella la identidad y paradójicamente también su extrañamiento. Desde imaginarios

El poema completo, como dijimos publicado en Canciones en 1927, dice: «La hoguera pone al campo de la tarde, / unas astas de ciervo enfurecido. / Todo el valle se tiende. Por sus lomos, / caracolea el vientecillo. // El aire cristaliza bajo el humo. / — Ojo de gato triste y amarillo—. / Yo en mis ojos, paseo por las ramas. / Las ramas se pasean por el río. // Llegan mis cosas esenciales. / Son estribillos de estribillos. / Entre los juncos y la baja tarde, / ¡qué raro que me llame Federico!». 
antagónicos, González recupera el gesto lorquiano para borronear los contornos figurativos del correlato autoral. El nombre compendia, también en su obra, el extrañamiento del yo («iqué raro!»), pero no porque su negación sea ya vía de inmersión en el cosmos, sino porque la rareza señala la infranqueable incertidumbre del ser, la constatación del espacio vacío nombrado.

Este poemario, Deixis en fantasma, es un intrigante ejemplo de los usos elípticos autorales en el asturiano, con sucesivas alegorías del proceso de autonominación. En el poema que comparte título con el libro dibuja a contraluz esa figura en filigrana que es el yo poético, aunque prescinda del nombre propio:

Solo presencia que no ocupa espacio, sombra o luz fiel al borde de mí mismo que ni el viento arrebata, ni la lluvia disuelve, ni el sol marchita, ni la noche apaga (2004: 405).

El resultado es una subjetividad perpleja, que se «ata a [su] vida dulcemente», pero no resulta ser «ni esto», «ni eso", sino "aquello». El yo se inscribe en el discurso como una señal, índice o shifter ("deixis», como alerta el título) provisoria, siempre nebulosa, en el «umbral» entre vida y escritura: esa "presencia que no ocupa espacio» y que se ubica apenas en un limbo, «al borde de mí mismo».

Si en este segundo momento de su escritura, atravesado por el desengaño y el cuestionamiento de la capacidad transitiva del lenguaje, los materiales lingüísticos, esquemáticos y formularios le servían como estructuras para intentar suplantar experiencias —aunque finalmente, como dirá el poeta (1980), siempre terminarán llenándose con estas-, el nombre propio será un elemento que le permite distanciarse del polo autobiográfico. Al cifrar el extrañamiento, esta nueva figuración agudiza los perfiles autoficcionales, más afines al simulacro, la distorsión, la impostura. Como esos hipotextos y marcos que funcionan como armazón lúdico y enfatizan la pérdida de fe en el lenguaje, el nombre propio será también el universo que concentre una identidad poética que replica y se disocia del espejo referencial. 
Este tono insolente o antipoético que, en especial a partir de «Preámbulo a un silencio», tiñe la poesía del asturiano y permite pensar en una segunda etapa de su obra, parece ser abandonado paulatinamente, primero en Otoños y otras luces de 2001, hasta alcanzar una dicción marcadamente elegíaca y desgarradora en Nada grave de 2008. Estos libros últimos representan un tercer y último momento de su poesía: se alejan de la inflexión humorística y mayoritariamente desacralizadora que había ocupado el centro de la escena, para dar cuenta de un nuevo rostro del "personaje poético», un sujeto que propone disolver la distancia entre poesía/vida para hacer coincidir, desde una vuelta de tuerca, los rostros y máscaras de la enunciación.

El nombre propio reaparece en el primer poema de Otoños $y$ otras luces, titulado «El otoño se acerca», aunque dicho texto había sido publicado en 2000, como uno de los textos inéditos de la antología del autor $101+19=120$ poemas. La elección onomástica queda encubierta, oculta; recae del lado primordialmente connotativo, pues «ángel» se introduce sin mayúscula, subrayando su condición de sustantivo común:

Se diría que aquí no pasa nada, pero un silencio súbito ilumina el prodigio:

ha pasado un ángel que se llamaba luz, o fuego, o vida. Y lo perdimos para siempre (2004: 455).

Estos breves versos cierran el poema culminando el proceso de distanciamiento respecto del valor designativo del nombre propio, que signaba la escena en sus usos anteriores ${ }^{8}$. Si en primer término «Ángel González» simbolizaba la configuración más definida de esa objetivación del poeta que, en la superposición nominal, alentaba la identificación con el poeta empírico; y si, luego, la supresión patronímica demarcaba un nuevo rostro de ese personaje poético - escéptico, enajenado, más alejado del polo autobiográfico-, riormente, a una antología del autor publicada en 1996, con introducción de Víctor García de la Concha: Luz, o fuego, o vida. 
aquí, en este tercer uso, la estrategia da cuenta del proceso de borramiento de dicho personaje.

Este derrotero será extremado en el póstumo Nada grave, donde la utilización nominal se anula, para dar paso a los últimos trazos identitarios que cancelan la presencia del «personaje» para reafirmar al «hombre» sin más, desnudados los vínculos más ostensibles entre poesía y vida, sujeto y poeta. Se vislumbra de esta manera un movimiento paradójico: el énfasis en el nombre de autor, que presenta una versión histórica y civil del yo, constituye el mecanismo poético más evidente de objetivación de la voz poética, destacando las instancias más o menos distantes entre poeta y personaje; en tanto que la impersonalidad de la primera persona singular, que detenta el sujeto innominado del último poemario (y ya se ensayaba en Otoños y otras luces) da cuenta en cambio de una búsqueda por diluir estas fronteras.

Es interesante recordar que el propio poeta aludía a este giro final de su poesía, en una breve nota publicada en la revista El País Semanal, con un título elocuente, «¿Por qué escribo?»:

Me temo que, aunque siempre sostengo lo contrario, estoy cayendo en la tentación de creer que el poeta, bueno o malo, que mis versos configuran - ese personaje ilusorio que habla en los poemas-, soy efectivamente yo, y que el acabamiento del poeta significaría mi propio acabamiento [...] pues algo o mucho de mí persiste en lo que escribo (1998: 35).

La pregunta que elige como disparador de su ensayo parece la clave para situarnos en el espacio vacilante que tiene como centro la configuración de la voz poética en los estadios postreros de su escritura: ese "personaje ilusorio» que es sí mismo y otro a la vez; construcción literaria que, a lo largo del tiempo y de los versos, se representa, al decir del propio poeta, cada vez más próxima al autor.Vida y obra, entonces, parecen determinarse mutuamente en un vaivén sugerente que el propio González advierte en su faceta ensayística y revalida en su poemario póstumo.

El poema clave que nos enfrenta con este rostro último, figuración final en la que se prescinde ya del antropónimo, lo constituye el titulado «No solo el poeta es un fingidor».Ya el paratexto trasluce este nuevo emplazamiento, a través del evidente guiño intertextual con el celebérrimo poema de Pessoa; y luego porque pone de manifiesto una conexión con tópicos auriseculares —especialmente 
de procedencia barroca- que salpican, intermitente pero nítidamente, muchos de estos veintiocho textos póstumos. Imágenes de cuño barroco, como «el polvo enamorado» de Quevedo (2008:55), o la alusión a «la vida como río» — que, en la estela manriqueña, atraviesa el espíritu áureo-, la mención del siempre acechante memento homo (2008: 65) ${ }^{9}$, junto con la desoladora e implacable intuición del tempus fugit, sombra acuciante que tiñe todos los textos, representan diversas aristas que actualizan antiguas e inexorables preocupaciones que han asediado desde tiempos remotos la literatura y, entre ellos, al propio poeta. A estos, no obstante, puede añadirse un nuevo vínculo con las cavilaciones barrocas que surge, primordialmente, del mencionado paratexto de evocación pessoana: el theatrum mundi. Por un lado, en obvia remisión intertextual, en tal sentencia se retoma y reafirma el carácter de artificio e invención de la identidad poética, a través de los conocidos versos del portugués que compendian muchos de los postulados teóricos en torno de la ficcionalidad de la palabra poética: «Finge tão completamente / que chega a fingir que é dor / a dor que deveras sente».

Sin embargo, en la actualización gonzaliana, este "fingimiento» no alude solamente al rostro discursivo del poeta como personaje sino, a la vez, al poeta en su existencia histórica. Así lo explicita el propio texto en la yuxtaposición aclaratoria de los primeros versos, que dan cuenta, en simultáneo, de un talante ficticio que concierne pues no solo al "personaje poético", sino también al escritor, otro actor, como decíamos, pero de una primera y gran representación: la del hombre y el mundo, bajo el revisitado escenario del «gran teatro del mundo»:

Yo soy un fingidor; yo, no el poeta.

Ahora habla el hombre:

Sí, soy un fingidor.

Ved mi sonrisa (2008: 49).

En el trazado póstumo se acude explícitamente a la singularización pronominal en una utilización que, de modo manifiesto, distancia al yo del él: como el «poeta» que finge en la escena poética, el hombre finge también en su discurrir vital, en una actuación que

9 Esta locución latina forma parte de la frase «Memento homo, quia pulvis es et in pulverem reverteris», cuya traducción sería «Recuerda, hombre, que polvo eres y al polvo regresarás». Esta se encuentra en la Biblia, en el Génesis $(3,19)$, y solía utilizarse por los sacerdotes el miércoles de ceniza en el rito de la imposición de ceniza. 
atañe - previsiblemente, de acuerdo al tenor del poemario- a una mentida felicidad, cifrada en la idea de la «sonrisa».

Por último, parece lícito asimismo advertir un puente intratextual a través del cual, circularmente, estos últimos trazos escriturarios se enhebran con los primeros, a partir del último poema de Nada grave que, tras más de cinco décadas, refleja en espejo renovado y postrero el lejano «Para que yo me llame Ángel González», de 1956. Si en su retrato de presentación el sujeto se afirmaba en el tiempo diacrónico y en la cronología genealógica (en una temporalidad histórica, secular, cosmológica y, sobre todo, vitalista), el elocuente "Caída» que cierra el poemario, como contraparte, alude también a una nueva trayectoria. No obstante, esta vez, el proceso no concernirá a esta imagen cara al «alumbramiento», al «resultado» y al «fruto", sino, en cambio, a un movimiento que es, esencialmente, repliegue abismado en la propia subjetividad, en una figuración metafórica de la idea de muerte que vertebra el poemario y que se revela como la «nada grave» (perdido ya del todo el nombre propio):

Y me vuelvo a caer desde mí mismo

al vacío,

a la nada.

¡Qué pirueta!

¿Desciendo o vuelo?

No lo sé.

Recibo

el golpe de rigor, y me incorporo.

Me toco para ver si hubo gran daño, mas no me encuentro.

Mi cuerpo, ¿dónde está?

Me duele solo el alma.

Nada grave (2008: 73).

Este rostro terminal es un rostro post-mortem; una última mirada que ya no atañe al discurrir exterior sino, en cambio, a la contemplación absorta y meditativa del "postrer día» - trágica ironía para nosotros que, como lectores de este libro, actualizamos el final biográfico del autor real, cuya voz nos llega también póstumamente- - A su vez, parece interesante destacar el guiño, tal vez más oblicuo, que reenvía también desde este texto final a aquel poema-prólogo en la alusión perifrástica al nombre propio en su valor semántico. En su primera aparición, se ensayaba tímidamente el juego connotativo que alcanzaría su auge posteriormente — - para 
que mi ser pese sobre el suelo»-, y esta significación parece ser retomada aquí en la interrogación del quinto verso, cuyos términos opuestos permiten entrever asimismo la remisión al carácter etéreo del antropónimo: «¿Desciendo o vuelo? / No lo sé».

Finalmente, si hemos visto que las estampas autoficcionales —aún carentes de la inscripción onomástica, como en esta última figuración - acompasan el eje autorreferencial de la poesía, esta conjunción dialéctica asoma también en esta etapa final. Especialmente, esta confluencia se observa al enfatizarse en este poemario una de las caras más sugerentes y originales de la identidad poética: la del lector. De esta manera, en desmedro del espacio productivo, escriturario, del sujeto en su labor autoral, se privilegia, en cambio, el terreno de la recepción y el orbe del sujeto-lector. Este corrimiento se observa en textos como «Leo poemas» y «La verdad de la mentira», que diseñan un lector-cómplice en la línea evidente de la "poesía de la experiencia», en una apuesta tendiente a la identificación y el reconocimiento afectivo entre la experiencia discursiva que conecta a autor y lector, como sujetos partícipes de un mismo proceso ${ }^{10}$. En el primero, en clave singular, la experiencia lectora determina dicha identificación a partir de esta noción de "experiencia posible», que conjuga la complicidad entre vida y literatura: «Leo poemas al azar / [...] cuando me encuentro un verso triste, / siento en el alma como una caricia. / No es que me alivie la tristeza ajena; / es que me siento menos solo» (2008: 39). En el segundo, este lector cómplice será enunciado desde una impersonal tercera persona, que actualiza la empatía y la reciprocidad entre escritura y vida:

Al lector se le llenaron de pronto los ojos de lágrimas, y una voz cariñosa le susurró al oído:

— ¿Por qué lloras, si todo en ese libro es de mentira?

Y él respondió:

$$
\text { 一Lo sé; }
$$

pero lo que yo siento es de verdad (2008: 41).

En la configuración multifacética y polivalente del sujeto autoficcional —o del personaje poético, o "personaje ilusorio», en

10 A la vez, la conexión con la lectura aparece también, de manera tal vez más oblicua, en los dos poemas titulados "Vista cansada», en diálogo/homenaje explícito al libro homónimo de García Montero del 2008, en los cuales resuena por su parte, de manera evidente, el tono proverbial y sentencioso del maestro Machado, especialmente en sus «Proverbios y cantares». 
palabras del ovetense- - se revela una de las más profundas y esenciales conexiones con el maestro sevillano. Coloquialismo, "palabra en el tiempo", conjugación de intimidad e historia a través de la esfera de los sentimientos, son algunas de las más ostensibles filiaciones entre ambos poetas. Asimismo, la creación consciente y definida de este personaje otro que recorre sus páginas es también una de las herencias más profundas de Machado. Este, como los apócrifos del maestro, sirve para comprender - como apunta García Montero- «que el poema no surge del desahogo sincero de un yo sensible, sino de la meditada construcción de un personaje literario»; lo primordial, en ambos, es la lúcida convicción de que la poesía es «representación, oficio, capacidad para crear las condiciones necesarias para que este personaje se desenvuelva en la escena de los versos con una seductora naturalidad» (1999: 35). Felipe Benítez Reyes decía en 2008, en el mismo sentido, que en la poesía —al igual que en el teatro- opera una fórmula en apariencia paradójica:

cuanto más se gesticula, cuantos más aspavientos y muecas practica, menos convincente resulta el actor, y más grotesco, precisamente porque está quebrantando un código básico: el arte no es un artificio que busca la artificiosidad, sino un artificio que pretende ocultar su condición de artificio (2008: 2).

Como vimos, esta figuración sobrevuela la escritura del asturiano reafirmando, en ocasiones, su estatuto objetivado y autónomo - conservando empero, siempre, en la coincidencia nominal, un halo de ambigüedad y sospecha- y, luego, difuminando sus contornos verbales hasta desaparecer y renacer — «Ĺzaro alegre», dirá en 1965, en «Me basta así», y «Orazal», en 2008 - en una primera persona que, sin nombre propio, conjuga verbo y vida en los últimos trazos líricos.

En el ya citado artículo «¿Por qué escribo?», González cerrará sus cavilaciones refiriéndose a esta concordancia intrínseca entre ficción y vida: «Me resisto a confinar en el pasado ese residuo de mí mismo, a desprenderme de ese yo que es otro, pero que ahora, cuando los dos estamos acercándonos a un final inevitable, noto que me hace muchísima compañía» (1998: 35). En este gesto final se reivindica una última y profunda conexión con la alteridad, en la senda cincelada por Machado: desde la complementariedad, la convivencia y la cordialidad entre esos múltiples yos en que se escinde la singularidad. En contraste y desde otras vías, Gil de Biedma 
tramará y ejecutará en sus Poemas póstumos la muerte irremediable de su otro yo, en un final previsible, en la línea anglosajona de los aciagos doppelgänger.

\section{CAVILACIONES IDENTITARIAS: LOS ECOS DE UN NOMBRE...}

El nombre propio del autor enhebra pues en el eje autoficcional distintos momentos de su obra, expresando matices diversos de sus concepciones auto y metapoéticas. El antropónimo es el que compendia el paulatino escepticismo respecto de la capacidad transitiva del lenguaje, el cuestionamiento — tan radical como pasajero- respecto de la compleja relación entre las palabras y las cosas. Así, «Ángel González» será sustituido por «Ángel»-y luego, «ángel» — para traducir desde estas variaciones nominales los múltiples perfiles identitarios, afines a las variaciones que atraviesan su pensamiento y su decir poético. Si bien la equivalencia entre «decir» $\mathrm{y}$ «hacer», que impulsaba la escritura más utópica de los «sociales mayores», es advertida tempranamente por González como un dictum, sus primeros poemarios - $\mathrm{y}$, en ellos, las primeras autonominaciones - revelan el trazado genealógico e historicista, el contorno más «social» del personaje en que se objetiva el poeta.

Estas primeras certezas irán diluyéndose y reemplazándose por visiones más críticas, que ponen de relieve la banalización y desacralización de esa figuración inicial, dispersa y diseminada en imágenes fragmentarias, relativas, que distorsionan de manera cada vez más ostensible el rostro del poeta que se esconde tras el nombre propio: un nuevo «Ángel» enajenado, síntesis del extrañamiento. No obstante, al final se retorna a ese "convencimiento» que había caracterizado sus inicios y que nunca se abandona del todo: más allá de la lucidez y la conciencia desoladora de la «inutilidad de todas las palabras», se elige siempre la poesía como oficio ético y compromiso moral. Por eso, en sus tramos últimos, el yo reivindica al «hombre» que se reconoce bajo el halo pessoano «otro actor» - relativo, variable, contradictorio- en el escenario del theatrum mundi.

El subtítulo elegido para estas reflexiones finales remeda la conocida "Historia de los ecos de un nombre», de las Otras inquisiciones de Jorge Luis Borges. Esta referencia al término de nuestro recorrido nos parece acertada y sugerente, no solo por la obvia 
importancia de la (auto)nominación en el escritor argentino, sino también por la imaginería mítica y atávica con que se envuelve el nombre en dicho ensayo. Allí, a partir de la «lección original» de Moisés en el Éxodo, que pregunta a Dios «Su Nombre», señala el autor que «quizás no huelgue recordar que para el pensamiento mágico, o primitivo, los nombres no son símbolos arbitrarios sino parte vital de lo que definen» (Borges, 2005: 197). Los nombres propios representan — no solo para la lingüística o la gramática, sino también para la antropología, la etnografia, etc. - una de las clases de palabra más complejas. Sus letras encierran un profundo misterio y un halo enigmático, especialmente porque implican un trasfondo acechante: el de una presencia cifrada en el mundo.

Así, la autonominación en la poesía de Ángel González permite dar cuenta de una figuración que se modula en el espacio bifronte de la perplejidad: el sí y el no en simultáneo. Entre el autor empírico y el ser de papel, entre el hombre y el personaje, el nombre propio permite a la vez la extrañeza («lo raro») y el reconocimiento («lo mismo»), una radical incertidumbre que reclama lectores audaces, dispuestos al juego siempre irresuelto de la autoficción, nuevos cómplices en la incesante rueda que entrelaza vida y poesía. 


\section{BIBLIOGRAFÍA}

Abuín GonZÁLEz, Ángel (1998). «El poeta como homo duplex: ironía romántica y duplicidad enunciativa», en Teoría del poema: la enunciación lírica, eds. Fernando Cabo Aseguinolaza y Germán Gullón, Amsterdam/Atlanta, Rodopi, pp. 111-134.

Aguiar e Silva,Vítor Manuel (1996). Teoría de la literatura, Madrid, Gredos.

Alarcos Llorach, Emilio (1996). La poesía de Ángel González, Oviedo, Nobel.

Armisén, Antonio (1998). «Sobre el hombre y el nombre: Notas de lectura a "Para que yo me llame Ángel González”», Grama y Cal: Revista Insular de Filología, 2, pp. 129-146.

Ballart, Pere (1994). Eironeia. La figuración irónica en el discurso literario moderno, Barcelona, Quaderns Crema.

Benítez Reyes, Felipe (2008). «La gravedad de Ángel González», Clarín. Revista de Nueva Literatura, 77, pp. 50-53.

Benson, Douglas K. (1981). «La ironía, la función del hablante y la experiencia del lector en la poesía de Ángel González», Hispania, 64, pp. 570-581.

Borges, Jorge Luis (2005). Otras inquisiciones, Buenos Aires, Emecé.

Bourdieu, Pierre (1997). «La ilusión biográfica», en Razones prácticas.

Sobre la teoría de la acción, Barcelona, Anagrama, pp. 74-83.

Caffarato, Mauro (2008). «La importancia de llamarse Ángel González», Cuadernos Hispanoamericanos, Extra 17 [Los Complementarios. Ángel González], pp. 84-97.

Campbell, Federico (1970). «Ángel González o la desesperanza» (entrevista con Ángel González), en Infame turba, Barcelona, Lumen, pp. 367-379.

CAÑAs, Dionisio (1980). «La polifonía poética de Ángel González», El País, 17 de agosto.

Cомвe, Dominique (1999). «La referencia desdoblada: el sujeto lírico entre la ficción y la autobiografia» en Teorías sobre la lírica, ed. Fernando Cabo, Madrid, Arco/Libros, pp. 127-153.

García de la Concha,Víctor (1996). «Introducción» a Ángel

González, Luz, o fuego, o vida, selección del autor, Salamanca,

Ediciones Universidad de Salamanca y Patrimonio Nacional.

García Montero, Luis (1999). «Prólogo» a Ángel González, Antonio Machado, Madrid, Alfaguara, pp. 15-40. 
— (2000). «Impresión de Ángel González», en Ángel

González, 101+19=120 poemas, Madrid,Visor.

GonzÁlez, Ángel (1980). «Prólogo» a Poemas, ed. del autor, Madrid, Cátedra, pp. 13-26.

— (1998). «¿Por qué escribo?», El País Semanal, 4 de enero, p. 35.

- (2004). Palabra sobre palabra, Barcelona, Seix Barral.

- (2008). Nada grave, pról. Luis García Montero, Madrid,Visor (Col. «Palabra de honor»).

Jiménez, José Olivio (1998). Diez años de poesía española 1960-1970, Madrid, RIALP.

KirkPATrick, Susan (1991). Las Románticas. Escritoras y

subjetividad: España 1835-1850, Madrid, Cátedra.

Lejeune, Philippe (1994). El pacto autobiográfico y otros

estudios, Madrid, Megazul/Endymion.

Leuci,Verónica (2008). «Ángel González: la cifra de múltiples versiones»,

Cuadernos para Investigación de la Literatura Hispánica, 33, enero.

Payeras Grau, María (2009). El sueño de la realidad. Poesía y poética

de Ángel González, Santa Cruz de Tenerife, La Página.

Romano, Marcela (2003). Almas en borrador. Sobre la poesía de Ángel

González y Jaime Gil de Biedma, Mar del Plata, Martín.

SCArano, Laura (2002). «Los paisajes urbanos de Ángel González», Litoral, 233, pp. 295-299.

- (2003). «De los álamos vengo...: entrevista al poeta español

Ángel González», Olivar [on line], 4. 4, pp. 161-175.

- (2011a). «Metapoeta: el autor en el poema», Boletín Hispánico Helvético.

Historia, Teoría(s), Prácticas Culturales, 17-18, pp. 321-346.

— (2011b). «Poesía y nombre de autor: entre el imaginario

autobiográfico y la autoficción», Celehis, 22. 20, pp. 219-240.

- (2011c). «Nada grave o grave nada: la mueca póstuma de

Ángel González», Archivum, LX, pp. 9-25.

- (2013). "Metapoetas de carne y verso», en La poesía en su laberinto. AutoRepresentacioneS

I, ed. Laura Scarano, Binges, Editions Orbis Tertius, pp. 225-241.

- (2014). Vidas en verso. Autoficciones poéticas (Estudio y

Antología), Santa Fe, Editorial de la Universidad del Litoral.

Sobejano, Gonzalo (1987). «Salvación de la prosa, belleza de la necesidad en

la poesía de Ángel González», en Simposio-Homenaje a Ángel González, eds.

Susana Rivera y Tomás Ruiz Fábrega, Madrid, José Esteban, pp. 23-54. 